\title{
Two enzyme linked immunosorbent assays for detecting antibodies against meningococcal capsular polysaccharides $\mathrm{A}$ and $\mathrm{C}$
}

\author{
O A O Akinwolere, D S Kumararatne, R Bartlett, D M Goodall, D Catty
}

\begin{abstract}
Aims-To evaluate two of the recent methods of coating microtitre plates in the enzyme linked immunosorbent assay (ELISA) for detecting human antibodies against meningococcal capsular polysaccharides $A$ and $C$ with a view to validating a specific meningococcal antibody assay for routine clinical use.
\end{abstract}

Methods-Two four-layer ELISA protocols were standardised: one method utilised meningococcal polysaccharides conjugated to poly-L-lysine polypeptide for coating the microtitre plates; another used polysaccharides mixed with methylated human serum albumin (mHSA). Titration curves were plotted for the ELISAs and the squared Pearson correlation coefficient $\left(\mathbf{R}^{2}\right)$ was used to determine the degree of accuracy of fit of the curves. Specificity tests were performed by inhibition and adsorption studies.

Results-Both methods gave good titration curves with a high $R^{2}$ of $>0.98$, indicating a high degree of accuracy in forming the curves. The titration end point after vaccination, obtained by the mHSA method, was 20 times higher, however, than that obtained by the poly-L-lysine method. Specificity tests showed that in the ELISA using polysaccharide/poly-L-lysine, antibody activity of a pre-vaccination serum sample was inhibited by $37 \%$, and of post-vaccination serum by $50 \%$ with 1000 -fold excess antigen. Antibody activity (postvaccination) was reduced by $51 \%$ and $59 \%$, respectively, by adsorption with antigen-coated Sepharose beads or adsorption with suspensions of killed meningococci. In contrast, antibody activity of a pre-vaccination serum was inhibited by $60 \%$ and a post-vaccination serum by $90 \%$ in ELISA employing polysaccharides mixed with mHSA. Reproducibility was better with the use of methylated human serum albumin than with poly-L-lysine; the former showed intrabatch and interbatch coefficients of variation of $4 \%$ and $2 \%$, respectively, compared with $43 \%$ (intrabatch) and $16 \%$ (interbatch) obtained with the poly-Llysine.

Conclusion-It is concluded that the antibody assay using meningococcal polysaccharides groups $A$ and $C$ mixed with mHSA is much better than that using polysaccharides coupled with poly-Llysine.

$(\mathfrak{A}$ Clin Pathol 1994;47:405-410)

Neisseria meningitidis is the causative organism in meningococcal disease, including septicaemia and meningitis. Meningococcal meningitis has a worldwide distribution, either in the endemic form in industrialised countries or as epidemics in developing countries. ${ }^{1}$ Epidemics are now rare in the temperate countries but the number of cases in parts of Europe increased suddenly in the late 1980 s, $^{2}$ reaching epidemic levels in Finland, Norway, The Netherlands, Spain and the United Kingdom. $N$ meningitidis groups $\mathrm{A}, \mathrm{B}$, and $C$ account for more than $90 \%$ of the isolates from patients. ${ }^{3}$ In the United Kingdom, infections caused by group $\mathrm{C}$ are not uncommon, accounting for $40 \%$ of infections in $1987,{ }^{4}$ and they still account for about a third of all meningococcal disease. ${ }^{5}$ Group A strains account for $2 \%{ }^{4}$; group B infections still predominate.

Vaccines are available for groups A and C (as well as groups $Y$ and W135) but not group B. ${ }^{6-8}$ Antibodies against the meningococcal capsular polysaccharides (MCP) groups A and $C$ are protective in adults and children above 2 years, ${ }^{68}$ and antibodies have been detected by indirect haemagglutination four years after vaccination. ${ }^{9} \mathrm{~A}$ more sensitive and specific method for quantitating antibody responses to vaccinations needs to be found Although the enzyme linked immunosorbent assay (ELISA) has often been used for measuring antibodies to protein antigens, its use for measuring antibodies to purified cell surface carbohydrates is often hindered by the failure of polysaccharides to adhere effectively to the polystyrene solid phase of the ELISA Negatively charged polysaccharides, such as meningococcal capsular polysaccharides $\mathrm{A}$ or C, do not adsorb easily to polystyrene commonly used as the solid phase in ELISA. Various methods have been developed to bind polysaccharides to microtitre plates. These include covalent binding to tyramine ${ }^{10}$ and to poly-L-lysine, ${ }^{11}$ use of capture antibodies ${ }^{12}$ and mixing with methylated human serum albumin (mHSA) ${ }^{13}$

This study evaluates the use of two ELISA methods for the detection of specific antibodies against meningococcal capsular polysaccharides groups $A$ and $C$ (MCP-A and MCP-C)
Infection

Correspondence to: Dr A O Akinwolere 27 October 1993 
in which the microtitre plates were coated with MCP either covalently bound to poly-Llysine or mixed with mHSA.

\section{Methods}

$N$ meningitidis group $\mathrm{A}$ and $\mathrm{C}$ capsular polysaccharides were kindly provided by Dr GM Carlone (Meningitis and Special Pathogens Branch, National Center for Infectious Diseases, Centers for Disease Control, Atlanta, Georgia, USA). A divalent meningococcal polysaccharide vaccine [Mengivac (A $+\mathrm{C}$ ), Institute Merieux, Lyon, France] was also investigated as a source of combined antigens. The single antigens were reconstituted with sterile water $(1 \mathrm{mg} / \mathrm{ml})$ and stored at $4^{\circ} \mathrm{C}$ before use, while lyophilised vaccine was stored at $4^{\circ} \mathrm{C}$ and used after reconstitution with proprietary diluent.

The method of Messina and colleagues ${ }^{11}$ was modified to bind, covalently, poly-Llysine polypeptide to meningococcal polysaccharide vaccine by using cyanuric chloride as the coupling agent. Briefly, $100 \mu \mathrm{l}$ of the polysaccharides were made alkaline with $500 \mu \mathrm{l} \mathrm{NaOH}(0.01 \mathrm{M})$, using $100 \mu \mathrm{l}$ of phenolphthalein $(0.001 \%)$ as an indicator, followed by activation of the polysaccharides by adding $0.5 \mathrm{mg}$ cyanuric chloride for 10 seconds. Poly-L-lysine $(0 \cdot 1 \%)(100 \mu \mathrm{l})$ was then mixed with the activated polysaccharides and refrigerated at $4^{\circ} \mathrm{C}$ for two hours. The final concentration of the polysaccharides in the conjugate was $123.8 \mu \mathrm{g} / \mathrm{ml}$ while that of the poly-L-lysine was $133.3 \mu \mathrm{g} / \mathrm{ml}$.

mHSA was prepared by using human serum albumin (HSA) $(20 \% \mathrm{w} / \mathrm{v})$ solution (Zenalb 20, BPL Bio Products Laboratory, UK) as the starting material. Briefly, $2.5 \mathrm{~g}$ $(20 \mathrm{ml}) \mathrm{HSA}$ was mixed with four volumes of cold ethanol and left at $-20^{\circ} \mathrm{C}$ for one hour. The solution was centrifuged at $3000 \mathrm{rpm}$ with a microfuge for five minutes before washing the precipitate once with ethanol. The pellets were suspended in $250 \mathrm{ml}$ methanol, and $2 \cdot 1 \mathrm{ml}$ of concentrated hydrochloric acid was added dropwise. The mixture was allowed to stand at room temperature in the dark for three days with slow stirring. The suspension was centrifuged at $3000 \mathrm{rpm}$ for five minutes and the precipitate washed twice with methanol and twice with anhydrous ether. The mHSA was collected on filter paper, dried overnight over potassium hydroxide in a desiccator, and stored in an airtight container in a refrigerator $\left(4^{\circ} \mathrm{C}\right)$. A stock solution of $\mathrm{mHSA}$ in distilled water $(1 \mathrm{mg} / \mathrm{ml})$ was stored at $4^{\circ} \mathrm{C}$. Working solutions of mHSA were made freshly by diluting stock solution in phosphate buffered saline (PBS, $10 \mathrm{mM}$, pH $7 \cdot 4)$. The working solution of mHSA was mixed dropwise with continuous rigorous stirring with MCP (A or C or A + C) in PBS (10 $\mathrm{mM}, \mathrm{pH} \mathrm{7.4)}$ to give a final concentration of 5 $\mu \mathrm{g} / \mathrm{ml}$ of either MCP or mHSA.

Lyophilised standard reference serum, CDC1992, provided by Dr GM Carlone, was reconstituted with sterile water while test serum samples were obtained from an adult volunteer (A) who was vaccinated with
Mengivac $(A+C)$ vaccine. The pre-vaccination sample (Ao) was collected just before vaccination while the post-vaccination sample (A1) was obtained three months after vaccination. A post-tetanus toxoid and postpneumococcal vaccination (but not postmeningococcal vaccination) pooled human serum sample (PP) was provided by the Department of Immunology, Dudley Road Hospital, Birmingham, UK, while serum from a hypogammaglobulinaemic patient (ADS) was provided by the Clinical Immunology Services, Medical School, Birmingham. All serum samples were stored at $-20^{\circ} \mathrm{C}$.

All monoclonal antibodies used in this study were produced at Recognition Sciences Ltd., University of Birmingham. These monoclonal antibodies were: R10Z8E9 for pan IgG; 2D7 for IgA; and CH6 for IgM. The conjugate was a polyclonal sheep antimouse immunoglobulin (WHO Collaborating Centre for Immunological Reagents, University of Birmingham) adsorbed against human immunoglobulin and conjugated to horseradish peroxidase.

\section{ELISA PROCEDURES}

ELISA with MCP/poly-L-lysine conjugate

coating

Microtitre plates [Nunc Immunoplate I, Gibco Ltd., Inchinnen, UK] were coated overnight at $4^{\circ} \mathrm{C}$ with $90 \mu \mathrm{l}$ of the $\mathrm{MCP} /$ polyL-lysine conjugate at an optimal concentration of $0.1 \mu \mathrm{g} / \mathrm{ml}$ in carbonate/bicarbonate $(0.05 \mathrm{M})$ coating buffer, $\mathrm{pH} 9 \cdot 5$. The wells were then incubated sequentially with: (1) $90 \mu \mathrm{l}$ reference or test serum diluted serially in bovine serum albumin (BSA) $(1 \% \mathrm{w} / \mathrm{v})$ in PBS (10 mM, pH 7.4) containing 0.05\% (v/v) Tween 20 (PBS-T, Sigma Chemical Co Ltd, Poole) at $4^{\circ} \mathrm{C}$ for 48 hours; (2) $90 \mu$ l specific murine monoclonal antibodies to human immunoglobulin G (R10Z8E9, Recognition Sciences Ltd, Birmingham) diluted 1 in 250 in PBS-T containing $1 \%$ $\mathrm{BSA}$, at $37^{\circ} \mathrm{C}$ for one hour; (3) $90 \mu \mathrm{l}$ sheep anti-mouse immunoglobulin horseradish peroxidase conjugate (WHO Collaborating Centre for Immunological Reagents, University of Birmingham), diluted 1 in 1000 in PBS-T containing $1 \% \mathrm{BSA}$ and normal sheep serum (NSS) $(0.5 \% \mathrm{v} / \mathrm{v})$.

Wells were washed four times with PBS-T after each incubation. The assay was developed with 90 Ìl of OPD substrate per well $(0.4 \mathrm{mg} / \mathrm{ml}$ o-phenylenediamine dihydrochloride; Sigma) in a $0.15 \mathrm{M}$ phosphate citrate buffer $(\mathrm{pH} 5.0)$ containing $0.012 \%$ hydrogen peroxide $\left(\mathrm{H}_{2} \mathrm{O}_{2} ; \mathrm{BDH}\right.$ Ltd, Poole, UK). Sulphuric acid $(25 \mu \mathrm{l}(20 \% \mathrm{v} / \mathrm{v})$ per well) was used to stop the colour reaction after optimal development and the plates were read by absorbance at $492 \mathrm{~nm}$ using an automated ELISA reader (Anthos Reader 2001, Anthos Labtec Instruments Ltd, Basingstoke, UK).

ELISA WITH MCP/mHSA MIXTURE COATING This procedure was modified from the method described by Arakere and Frasch ${ }^{13}$ and by Carlone et al. ${ }^{14}$ Briefly, $N$ meningitidis 
polysaccharide groups $\mathrm{A}$ or $\mathrm{C}$ or $\mathrm{A}+\mathrm{C}$, in coating buffer (10 mM PBS, pH 7.4) was added dropwise with continuous rigorous stirring to an equal volume of working solution of mHSA to give a final concentration of $5 \mu \mathrm{g} / \mathrm{ml}$ each $(10 \mu \mathrm{g} / \mathrm{ml}$ of Mengivac $(A+C))$. This was used to coat microtitre plates (Immulon 2, Dynatech Laboratories Ltd, Sussex, UK) overnight at $4^{\circ} \mathrm{C}(100 \mu \mathrm{l} /$ well $)$. The plates were washed five times with wash buffer (PBS-T), then $200 \mu \mathrm{l}$ of serum conjugate (SC) buffer (PBS-T containing $10 \% \mathrm{v} / \mathrm{v}$ fetal calf serum) was added to each well. Plates were left to stand at room temperature for one hour after which the buffer was decanted and plates blotted vigorously on absorbent towels. Serum diluted in S-C buffer $(200 \mu \mathrm{l})$ was added to the first well of the dilution series, after which nine duplicate serial dilutions of reference standard or test sera were made by well-to-well transfer in the microtitre plates using a multichannel pipette (100 $\mu \mathrm{l}$ was transferred and mixed five times in each well). The plates were covered and incubated overnight at $4^{\circ} \mathrm{C}$. Plates were washed five times as described above and the wells were then incubated at $37^{\circ} \mathrm{C}$ for one hour sequentially with: (1) $100 \mu \mathrm{l}$ of specific murine monoclonal antibodies to human immunoglobulins (G (R10Z8E9), A (2D7), or M (CH6), produced by Recognition Sciences Ltd, University of Birmingham), diluted appropriately in S-C buffer; (2) $100 \mu$ l sheep anti-mouse Ig horseradish peroxidase conjugate diluted in S-C buffer containing NSS $(0.5 \% \mathrm{v} / \mathrm{v})$.

The plates were washed five times after each step and the assay developed with $100 \mu$ l OPD substrate per well, as described before.

\section{STATISTICAL ANALYSIS AND INTERPRETATION OF ASSAYS}

Graphs of the absorbance against $\log _{10} x$ of the serum dilution were plotted using a standard computer program. These sigmoid scatter curves were expected to follow third order polynomial equations and therefore computerised methods for determining adequacy of curve fit were used. The squared Pearson correlation coefficient $\left(\mathbf{R}^{2}\right)$ was used to determine the degree of accuracy of fit between the experimental data and the model curves. A titration curve was obtained for each serum sample and, where appropriate, compared with the curve of a standard positive reference serum. The antibody titre for each individual was expressed as a reciprocal of the dilution of serum which gave an absorbance reading equivalent to one third the maximum value produced by the standard reference serum.

INHIBITION ASSAYS

Competitive inhibition was assessed using a single dilution of a serum sample. The dilution was chosen after comparing the inhibitions for serum dilutions between 1 in 20 and 1 in 160. Inhibition was at a maximum between 1 in 80 and 1 in 160 dilutions. The sera were diluted in PBS-T containing $10 \%$ polyethyl- ene glycol (BDH Ltd) or in S-C buffer, and distributed into nine aliquots for each buffer. Eight two-fold dilutions of $\mathrm{MCP}(\mathrm{A}+\mathrm{C})$ in PBS-T containing $10 \%$ polyethylene glycol or in S-C buffer were prepared starting at the highest concentration $(100 \mu \mathrm{g} / \mathrm{ml})$ and ending with the lowest concentration $(0.78 \mu \mathrm{g} / \mathrm{ml})$. An equal volume of a different serial dilution of $\mathrm{MCP}(\mathrm{A}+\mathrm{C})$ was added to each of eight aliquots containing serially diluted serum; the same volume of buffer alone was added to the ninth serum aliquot as the $0 \%$ inhibition control. The serum and polysaccharide dilutions were allowed to react for one hour at $37^{\circ} \mathrm{C}$ and antibody activity of the mixture was then determined by two ELISA procedures, as described before.

\section{ADSORPTION ASSAYS}

Adsorption of meningococcal antibodies was performed separately with: (1) MCP $(A+C)$-coated activated Sepharose beads (Sepharose 4B, Pharmacia Fine Chemicals, Herts, UK) using a method obtained from Pharmacia, as modified by the Immunodiagnostic Research Laboratory (IDRL), University of Birmingham; (2) suspensions of killed $N$ meningitidis serogroups $\mathrm{A}$ and $\mathrm{C}$ organisms (Public Health Laboratory Service, National Collection of Type Cultures, London, UK).

\section{Adsorption with antigens coated to activated Sepharose beads}

Cyanogen bromide $(0.01 \mathrm{~g})$ activated Sepharose beads (CN-Br Sepharose 4B, Pharmacia) were preswollen with $500 \mu \mathrm{l} \mathrm{HCl}(1 \mathrm{mM})$ in each of five Eppendorf tubes and washed with $1 \mathrm{ml} \mathrm{HCl}(1 \mathrm{mM})$ for five minutes at 6500 rpm using a microfuge. The supernatant fluid was discarded and $1 \mathrm{ml}$ of $\mathrm{MCP}(\mathrm{A}+\mathrm{C})$ / poly-L-lysine conjugate antigen, dialysed overnight at $4^{\circ} \mathrm{C}$ against $\mathrm{NaHCO}_{3}(0 \cdot 1 \mathrm{M}) /$ $\mathrm{NaCl}(0.5 \mathrm{M})$ buffer ( $\mathrm{pH} 8.3)$, was added. Uncoated Sepharose beads with buffer in five other tubes were used as controls. The tubes were rotated and mixed for two hours at room temperature and washed twice with $\mathrm{NaHCO}_{3} / \mathrm{NaCl}$ buffer (pH 8.3). The supernatant fluids were discarded and the antigen and controls were washed with three cycles of alternating $\mathrm{pH}$. Each cycle consisted of a wash using sodium acetate $(0 \cdot 1 \mathrm{M})$ /sodium chloride (1M) buffer ( $\mathrm{pH} 4)$, followed by a wash using borate $(0 \cdot 1 \mathrm{M}) / \mathrm{NaCl}(1 \mathrm{M})$ buffer $(\mathrm{pH} 8)$. The supernatant fluid was discarded after the final wash. One milli-litre each of five serum dilutions $(1$ in 10,1 in 40,1 in 80,1 in 160,1 in 640 in PBS-T containing 1\% BSA and 5\% polyethylene glycol) was added to the antigen and control tubes; duplicate serum dilutions were stored at $-20^{\circ} \mathrm{C}$ (as pre-adsorption sera). Adsorption was permitted at $37^{\circ} \mathrm{C}$ for two hours on a rotor and the tubes were then centrifuged at $6500 \mathrm{rpm}$ for five minutes. The supernatant fluids were stored at $-20^{\circ} \mathrm{C}$ (post-adsorption sera). The pre- and postadsorption sera were tested by ELISA using $\operatorname{MCP}(\mathrm{A}+\mathrm{C}) /$ poly-L-lysine conjugate coating, as described before. 
Figure 1 (A) ELISA curves of serum samples obtained from post-pool reference (PP), prevaccination $(A \mathrm{O})$, postvaccination $(A 1)$ and antibody deficient (ADS) subjects showing the squared Pearson correlation coefficient $\left(R^{2}\right)$ for each curve. Meningococcal capsular polysaccharide groups $A$ and $C$ vaccine (MCP $(A+C)$, conjugated to poly-L-lysine (PLL) were used to coat microtitre plates. The absorbance at $492 \mathrm{~nm}$ (ordinate) was plotted against the $\log _{10} x$ of serum dilutions (abscissa). (B) ELISA curves of serum samples (PP, Ao, $A 1, A D S)$ using $M C P(A+C)$ mixed with methylated human serum albumin ( $m H S A$ ) to coat microtitre plates, for comparison with fig $1 A$.

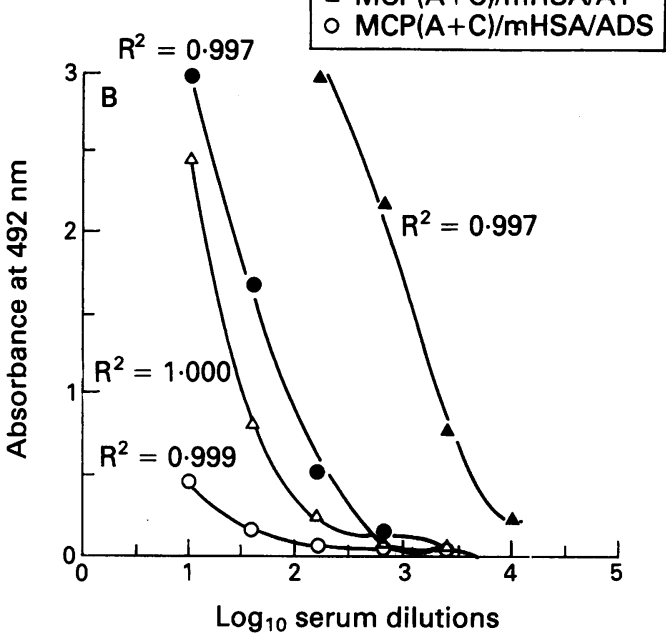

Adsorption with killed $N$ meningitidis, serogroups $A$ and $C$

Cultures of $N$ meningitidis (serogroup A (NCTC) number 10025, strain M1027) and serogroup C (NCTC number 8554, strain 1628) were made in Todd Hewitt Broth and colony counts were performed using a Miles and Misra surface viable count. ${ }^{27}$ The bacteria were killed by heating at $80^{\circ} \mathrm{C}$ for 20 minutes. Serial fourfold dilutions of serum ( 1 in 5,1 in 20,1 in 80,1 in 320 in PBS-T containing $1 \%$ BSA and 5\% polyethylene glycol) were made in bijou bottles and $500 \mu \mathrm{l}$ of each dilution was adsorbed, first with $500 \mu \mathrm{l}\left(2 \times 10^{9}\right.$ bacteria) suspension of killed $N$ meningitidis

Meningococcal antibody titres by ELISA methods

\begin{tabular}{|c|c|c|c|c|c|c|c|c|}
\hline \multirow[b]{3}{*}{ Serum } & \multirow{3}{*}{$\begin{array}{l}(P L L) \\
M C P \\
(A+C) \\
I g G\end{array}$} & \multicolumn{7}{|l|}{$(m H S A)$} \\
\hline & & \multirow{2}{*}{$\begin{array}{l}M C P \\
(A+C) \\
I g G\end{array}$} & \multirow{2}{*}{$\frac{(A)}{\operatorname{Ig} G}$} & \multicolumn{2}{|c|}{$M C P$} & \multicolumn{3}{|l|}{$\begin{array}{l}M C P \\
(C)\end{array}$} \\
\hline & & & & $I g A$ & IgM & $I g G$ & $\operatorname{Ig} A$ & $I g M$ \\
\hline $\begin{array}{l}\text { PP } \\
\text { Ao } \\
\text { A1 } \\
\text { ADS } \\
\text { CDC }\end{array}$ & $\begin{array}{r}66 \\
39 \\
105 \\
6\end{array}$ & $\begin{array}{r}86 \\
34 \\
2270 \\
2\end{array}$ & $\begin{array}{r}204 \\
42 \\
728 \\
<1\end{array}$ & $\begin{array}{l}10 \\
16 \\
79 \\
<1\end{array}$ & $\begin{array}{r}281 \\
174 \\
304 \\
<1\end{array}$ & $\begin{array}{r}16 \\
8 \\
3565 \\
1\end{array}$ & $\begin{array}{r}5 \\
<1 \\
728 \\
<1\end{array}$ & $\begin{array}{r}13 \\
16 \\
304 \\
<1\end{array}$ \\
\hline 1992 & ND & 5297 & 4898 & 530 & 1888 & 1000 & 221 & 239 \\
\hline
\end{tabular}

Meningococcal antibody titres (reciprocals) showing different immunoglobulin isotypes (IgG, IgA, and IgM) of serum samples (PP, Ao, A1, ADS, CDC 1992), using two ELISA methods (MCPImHSA and $M C P(P L L)$.

MCP group A or $C$ was used to coat microtitre plates in the MCP/mHSA ELISA methods. Antibody titres (IgG) for the MCP/poly-L-lysine and MCP/mHSA methods using divalen meningococcal vaccine $(A+C)$ are also shown. Titre of CDC 1992 was not determined (ND) using the divalent vaccine antigen. serogroup A and then with $500 \mu \mathrm{l}\left(1.8 \times 10^{9}\right.$ bacteria) suspension of killed $N$ meningitidis serogroup $\mathrm{C}$, for 30 minutes each at $37^{\circ} \mathrm{C}$ on a rotor. The Eppendorf tubes were centrifuged at $13000 \mathrm{rpm}$ for five minutes after adsorption with each bacterial strain and the supernatant fluids stored at $-20^{\circ} \mathrm{C}$. The pre- and post-adsorption sera were tested by ELISA using $\mathrm{MCP}(\mathrm{A}+\mathrm{C}) /$ poly-L-lysine conjugate coating, as described before.

\section{Results}

MENINGOCOCCAL ANTIBODY TITRES

The MCP/poly-L-lysine ELISA curves for various human sera (PP, Ao, $A 1$, and $A D S$ ) using divalent antigens $(A+C)$ are shown in fig $1 \mathrm{~A} ; \mathrm{MCP} / \mathrm{mHSA}$ ELISA curves for the same sera are shown for comparison in fig $1 B$. All the curves achieved a high squared Pearson correlation coefficient $\left(R^{2}>0.98\right)$, indicating a high degree of accuracy in forming the curves. The table shows the meningococcal antibody titres (IgG) determined for the sera using the $\mathrm{MCP} /$ poly-L-lysine and $\mathrm{MCP} / \mathrm{mHSA}$ assay methods; the titre of the post-vaccination serum, as measured by the $\mathrm{MCP} / \mathrm{mHSA}$ assay method, is 20 times higher than that measured by the MCP/poly-L-lysine method. The table also shows the antibody titres of the immunoglobulin isotypes using the monovalent antigens ( $\mathrm{A}$ or $\mathrm{C}$ ) with $\mathrm{MCP} / \mathrm{mHSA}$ ELISA.

SPECIFICITY ASSAYS

Competitive inhibition assays, as described for the two methods, showed less than $40 \%$ inhibition of antibody activity for the prevaccination serum (Ao) with the $\mathrm{MCP} /$ polyL-lysine ELISA, compared with $60 \%$ with the $\mathrm{MCP} / \mathrm{mHSA}$ ELISA. However, the antibody activity of the post-vaccination serum (A1) was inhibited by $50 \%$ using the MCP/poly-Llysine ELISA, and by $90 \%$ using the

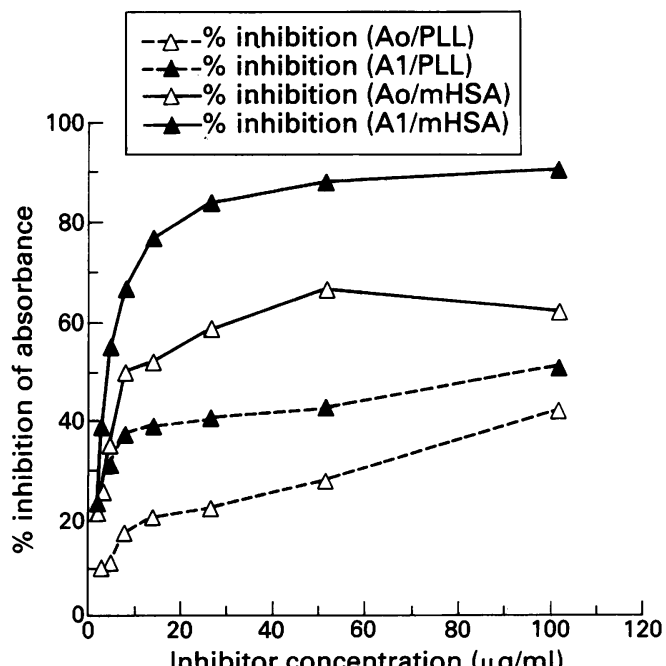

Figure 2 Shows ability to competitively inhibit antibody activity of pre-and post-vaccination samples with free meningococcal polysaccharides ( $A$ and $C$ ). The open symbols indicate the degree of inhibition achieved using pre-vaccination serum (Ao) and the closed symbols indicate the degree of inhibition with the post-vaccination serum (A1). The dotted lines represent the curves for the poly-L-lysine assay; the continuous lines represent the curves for the methylated human serum albumin assay. 
$\mathrm{MCP} / \mathrm{mHSA}$ ELISA (fig 2). Antibody activity in the post-vaccination serum was reduced by $51 \%$ after adsorption with antigen-coated Sepharose beads and maximally by $59 \%$ after adsorption with suspensions of killed meningococci, confirming the reduced specificity of the MCP/poly-L-lysine ELISA.

\section{REPRODUCIBILITY}

The MCP/poly-L-lysine ELISA gave antibody titre results that were less reproducible than the results obtained from the $\mathrm{MCP} / \mathrm{mHSA}$ ELISA. The intrabatch coefficient of variation (CV) using the MCP/poly-L-lysine ELISA was $43 \%$, while the interbatch $C V$ was $16 \%$. In contrast, the $\mathrm{CV}$ of the $\mathrm{MCP} / \mathrm{mHSA}$ was $4 \%$ (intrabatch) and $2 \%$ (interbatch).

\section{Discussion}

Immunisation with meningococcal polysaccharide vaccines results in induction of protective antibodies in human kind. In adults these antibodies belong to the three main immunologlobulin isotypes IgG, IgM, and IgA. ${ }^{15}$ It is not only important to measure antibody responses to vaccinations but also necessary to identify people with low numbers of antibodies who are at risk of meningococcal infections. Antibodies against meningococcal polysaccharides have been measured by various methods, including bacterial antibody assay and immunofluorescence, ${ }^{16}$ opsonisation activity, ${ }^{17}$ passive haemagglutination, ${ }^{18}$ latex agglutination, ${ }^{19}$ radioantigen binding assay $(\mathrm{RABA})^{20}$ and ELISA. ${ }^{21}$ Of these, ELISA lends itself best to a routine and simple protocol which can sensitively measure the amount of antibodies in sera. The ELISA can also separately measure the antibody titre of the three main immunoglobulin isotypes..$^{22}$ Other advantages of the ELISA include its relative simplicity, reagent stability, small sample volumes, and use of unsophisticated equipment. There is no universally standardised ELISA, however, for measuring antibodies against meningococcal capsular polysaccharides (MCP). We have standardised two fourlayer ELISA protocols for measuring specific antibodies against MCP groups $A$ and $C$. Serum IgG antibodies were detected using the divalent antigens (MCP-A $+\mathrm{C}$ ) and monovalent antigens (MCP-A or MCP-C). The method of coating microtitre plates with MCP covalently bound to poly-L-lysine was compared with MCP mixed with mHSA. Although both methods gave good titration curves, the antibody titre obtained with the latter method using the post-vaccination serum was 20 times higher than that obtained with the poly-L-lysine method. The mHSA assay seems to reveal much better the critical dominant epitope site for antibody response to vaccination while the poly-L-lysine conjugate does not. Therefore, poly-L-lysine might either have destroyed this critical epitope on the polysaccharide or the covalent bonding of the two might have resulted in the loss of expression of the epitope or the epitope was unavailable for antibody binding in the conjugate when adsorbed to the solid phase.

Carbohydrates, coupled with poly-L-lysine, were used as antigens for coating microtitre plates and were found to be sensitive and reproducible. ${ }^{11}$ This was attributed partly to the maintenance of a constant alkaline $\mathrm{pH}$ in the conjugation process. In our experience, the use of poly-L-lysine is sensitive but less reproducible, although an alkaline $\mathrm{pH}$ was also maintained during conjugation of MCP to poly-L-lysine; we found a high intrabatch coefficient of variation (43\%) and an interbatch coefficient of variation of $16 \%$. The type of microtitre plate used in the assay may also contribute to the high intrabatch variation; this was confirmed by maximal absorbance of control wells coated with the coating buffer alone. The competitive inhibition assay with the poly-L-lysine method showed $50 \%$ inhibition of antibody activity of the post-vaccination serum, indicating the presence of non-specific binding to poly-Llysine. This was also confirmed when poly-Llysine was used as antigen to coat microtitre plate wells directly for the assay or to coat Sepharose beads for adsorption before the assay. In both cases maximal binding of antibodies was observed over the entire range of serum dilutions used in the assay and up to $42 \%$ adsorption of antibody activity was achieved with poly-L-lysine (data not shown). These observations suggest that the use of meningococcal polysaccharides, coupled with poly-L-lysine, for coating microtitre plates, can produce non-specific binding of antibodies to the polypeptides and may not be ideal in ELISA for measuring antimeningococcal antibodies. Other workers also found that poly-Llysine produced non-specific absorbance with some sera in their meningococcal ELISA. ${ }^{13}$

mHSA mixed with meningococcal polysacharides, on the other hand, showed $90 \%$ inhibition of antibody activity of post-vaccination serum. This shows minimal non-specific binding to the mHSA. We also found the use of mHSA to be more reproducible with low coefficients of variation of $4 \%$ (intrabatch) and $2 \%$ (interbatch). These figures compare with less than $10 \%$ variations reported for other validated ELISAs for measuring antibodies against encapsulated bacteria. ${ }^{23}$ Our study has shown that the use of mHSA is better than that of poly-L-lysine for coating microtitre plates in meningococcal ELISA because it is more specific and more reproducible. We were also able to measure the different immunoglobulin isotypes of human antibodies against meningococcal polysaccharides groups $\mathrm{A}$ and $\mathrm{C}$ with this method.

It has been observed that standard ELISAs measure high avidity antibodies whereas amplified ELISAs can detect low avidity antibodies. ${ }^{24}$ In our study the prolonged incubation of serum for 48 hours with the poly-L-lysine method, and for 24 hours with the mHSA method, suggests that low avidity antibodies were being detected. It was possible to reduce this serum incubation time to one hour in the poly-L-lysine method, and obtain a similar absorbance value, in the presence of $10 \%$ polyethylene glycol. ${ }^{25}$ Detailed affinity studies are needed to confirm this observation. 
A Centers for Disease Control standard reference serum was used for standardising the meningococcal assay as a primary step for measuring meningococcal antibodies, but there is no comparable standard reference serum available from the United Kingdom or from Europe. When such a serum is readily available it should be possible to determine the exact antibody concentration of test samples when such a reference is included on each plate of an assay.

Meningococcal antibody titres measured with divalent vaccine antigens reflect the higher antibody response to one of the component antigens. Although divalent (or tetravalent) vaccines are more readily available commercially than monovalent ones, their use as a source of antigen for coating microtitre plates in meningococcal ELISA is likely to be less than ideal as the antibodies to predominant epitopes may mask or inhibit the binding of antibodies to other antigens in the coating mixture. Therefore, we agree with the use of monovalent meningococcal polysaccharide vaccines or purified meningococcal capsular polysaccharides as recommended by the World Health Organisation as this will give a more meaningful measure of antibody responses of the individual to each of the vaccine component antigens. At present there are no easily available commercial sources of single meningococcal polysaccharides, but standardised polysaccharides for these assays may be available through agencies like the WHO. The advantage of using monovalent polysaccharide antigen over a mixture of different types of meningococcal polysaccharides is that each test gives a full measure of all antibodies capable of binding the single antigen irrespective of any antibody cross-reactions that might be present in the sera. Similarities exist between the residues of the polysaccharides from meningococci groups $\mathrm{B}$ and $\mathrm{C}$ and Escherichia coli types $\mathrm{K} 1$ and $\mathrm{K} 92$, on the one hand, and of the polysaccharides of meningococci of groups W135 and Y on the other. We did not expect any cross-reactions between groups $\mathrm{A}$ and $\mathrm{B}$ or $\mathrm{C}$ meningococcal polysaccharide because the chemical structure of group A polysaccharide is distinctly different from that of groups B or C; moreover the possibility of cross-reactions between these groups and other polysaccharides have been studied in detail before..$^{21} 26$ They showed that cross-reactions only exist between group B meningococcal polysaccharide and $E$ coli type $\mathrm{K} 1$, but only minor reactions occur between group C polysaccharide and $E$ coli type $\mathrm{K} 92 .{ }^{21}$ No cross-reactions have so far been found between the meningococcal groups except a slight cross-reaction reported between almost identical polysaccharides like groups W135 and $\mathrm{Y}$ polysaccharides. ${ }^{26}$ Therefore, the ELISA using mHSA to coat microtitre plates will be useful in defining those at risk of meningococcal infections (groups A or C) and in quantitating human antibodies of different isotypes against meningococcal capsular polysaccharide $\mathrm{A}$ or $\mathrm{C}$ antigens.
The study was supported by a British Foreign and Commonwealth Office award to Dr OAO Akinwolere.

1 Achtman M, Crowe BA, Olyhoek A, Strittmatter W, Morelli G. Recent results on epidemic meningococca meningitis. $\mathcal{F}$ Med Microbiol 1988;26:172-7.

2 Duerden BI. Meningococcal infection. $f$ Med Microbiol 1988;26:161-87.

3 Gotschlich EC. Meningococcal meningitis. In: Germanier R, ed. Bacterial vaccines. Orlando, Florida: Academic Press Inc, 1984:237-55.

4 Jones DM. Epidemiology of meningococcal infection in England and Wales. $\mathcal{F}$ Med Microbiol $1988 ; 26: 165-8$.

5 Jones DM. Meningococcal vaccines. $₹$ Med Microbiol 1993; 38:77-8.

6 Artenstein MS, Gold R, Zimmerly JG, Wyle FA, Schneider $\mathrm{H}$, Harkins C. Prevention of meningococcal disease by group $\mathrm{C}$ polysaccharide vaccine. $N$ Engl $f \mathrm{Med}$ 1970;282:417-20

7 Gold R, Lepow ML, Goldschneider I, Draper TL Gotschlich EC. Clinical evaluation of group A and $C$ meningococcal polysaccharide vaccines in infants. $\mathcal{F} \mathrm{Clin}$ Invest 1975;56:1536-47.

8 Makela PH, Kayhty H, Weckstrom P, Sivonen A Renkonen OV. Effect of group A meningococcal vaccines in army recruits in Finland. Lancet 1975;ii:883-6.

9 Mohammed I, Onyemelukwe GC, Obineche EN, Gupta N, Oyeyinka GO. Control of epidemic meningococcal meningitis by mass vaccination $2:$ persistence of antibody meningitis by mass vaccination 2: persistence of antib

10 Anthony BF, Concepcion NF, McGeary SA, Ward JL Heiner DC, Shapshak P, et al. Immunospecificity and quantitation of an enzyme-linked immunosorbent assa for group B streptococcal antibody. $\mathcal{f}$ Clin Microbiol 1982;16:350-4.

11 Messina JP, Hickox PG, Lepow ML, Polara B, Venezia RA. Modification of a direct enzyme-linked immunosorbent assay for the detection of immunoglobulin $G$ and $M$ antibodies to pneumococcal capsular polysaccharide. $\mathcal{F}$ antibodies to pneumococcal
Clin Microbiol 1985;21:390-4.

12 Zigterman GJWJ, Verheul AFM, Ernste EBHW, et al. Measurement of the humoral response against Streptococcus pneumoniae type 3 capsular polysaccharide and oligosaccharide containing antigens by ELISA and ELISPOT techniques. $\mathcal{F}$ Immunol Methods 1988;106: 101-7.

13 Arakere G, Frasch CE. Specificity of antibodies to $O$ acetyl-positive and $\mathrm{O}$-acetyl-negative group $\mathrm{C}$ meningococcal polysaccharides in sera from vaccinees and carriers. Infect Immun 1991;59:4349-56.

14 Carlone GM, Frasch CE, Siber GR, et al. Multicenter comparison of levels of antibody to the Neisseria meningitidis group A capsular polysaccharide measured by using tidis group A capsular polysaccharide measured by using an enzyme-linked

15 Gotschlich EC, Goldschneider I, Artenstein MS. Human immunity to meningococcus 4 . Immunogenicity of group $\mathrm{A}$ and $\mathrm{C}$ meningococcal polysaccharides in human volunteers. $\mathcal{F}$ Exp Med 1969;129:1367-84.

16 Goldschneider I, Gotschlich EC, Artenstein MS. Human immunity to meningococcus 1 . The role of humoral antibodies. $₹$ Exp Med 1969;129:1307-26.

17 Roberts RB. The relationship between group A and group $C$ meningococcal polysaccharides and serum opsonins in meningococcal polysaccharides and
man. F Exp Med 1970;131:499-512.

18 Artenstein MS, Brandt BL, Tramont EC, Branche WE Fleet HD, Cohen RH. Serologic studies of meningococcal infection and polysaccharide vaccination. F Infect Dis 1971;124:277-88.

19 Tramont EC, Artenstein MS. Latex agglutination test for measurement of antibodies to meningococcal polysaccharides. Infect Immun 1972;5:346-51.

20 Brandt BL, Wyle FA, Artenstein MS. A radioactive antigen-binding for Neisseria meningitidis polysaccharide antibody. F Immunol 1972;108:913-20

21 Beuvery EC, van Delft RW, Tiesjema RH, Nagel J. The enzyme-linked immunosorbent assay of meningococcal and some related Escherichia coli polysaccharides. $7 \mathrm{Biol}$ Stand 1983;11:195-204.

22 Beuvery EC, Kayhty MH, Leussink AB, Kanhai V. Comparison of radioimmunoassay and enzyme-linked immunosorbent assay in measurement of antibodies to Neisseria meningitidis group A capsular polysaccharide. f Clin Microbiol 1984;20:672-6.

23 Hazlewood M, Nusrat $R$, Kumararatne DS, et al. The acquisition of anti-pneumococcal capsular polysaccharide, Haemophilus influenzae type $\mathrm{b}$ and tetanus toxoid antibodies with age, in the U.K. Clin Exp Immunol 1993;93:157-64

24 Butler JE, Feldbush TL, McGivern PL, Stewart N. The enzyme-linked immunosorbent assay (ELISA): a measure of antibody concentration or affinity? Immunochemistry 1978;15:131-6.

25 Akinwolere OAO. Standardisation of ELISA for detecting human antibodies against meningococcal capsular polyhuman antibodies against meningococcal capsular poly-
saccharides. (Thesis) Birmingham: University of Birmingham, 1992:1-200.

26 Bhattacharjee AK, Jennings HJ, Kenny CP, Martin A Smith ICP. Structural determination of the sialic acid Smith ICP. Structural determination of the sialic acid
polysaccharide antigens of Neisseria meningitidis serogroups $Y, W 135$ and BO. Can $\mathcal{F}$ Biochem 1976;54:1-8.

27 Miles AA, Misra SS. The estimation of bactericidal power of the blood. F Hyg Camb 1938;38:732-49. 